\title{
Acoustic analysis of Korean affricates produced by dysarthric speakers with cerebral palsy*
}

\author{
Jihyun Mun ${ }^{1} \cdot$ Sunhee $\mathrm{Kim}^{2} \cdot$ Minhwa Chung ${ }^{1, * *}$ \\ ${ }^{I}$ Department of Linguistics, Seoul Nationa University, Seoul, Korea \\ ${ }^{2}$ Department of French Language Education, Seoul National University, Seoul, Korea
}

\begin{abstract}
This study aims to analyze the acoustic characteristics of Korean affricates produced by dysarthric speakers with cerebral palsy. Korean fricatives and affricates are the consonants that are prone to errors in dysarthric speech, but previous studies have focused only on fricatives. For this study, three affricates $/ \mathrm{t} 6, \mathrm{t}_{6}{ }^{\mathrm{h}},{ }_{\mathrm{H}} \mathrm{t} /$ appearing at word initial and intervocalic positions produced by six mild-moderate male speakers of spastic dysarthria are selected from a QOLT database constructed in 2014. The parameters representing the acoustic characteristics of Korean affricates were extracted by using Praat: frication duration, closure duration, center of gravity, variance, skewness, kurtosis, and central moment. The results are as follows: 1) frication duration of the intervocalic affricates produced by dysarthric speakers was significantly longer than that of the non-disordered speakers; 2) the closure duration of dysarthric speakers was significantly longer; 3 ) in the case of the center of gravity, there was no significant difference between the two groups; 4) the skewness of the dysarthric speakers was significantly larger; and 5) the central moment of dysarthric speakers was significantly larger. This study investigated the characteristics of the affricates produced by dysarthric speakers and differences with non-disordered speakers.
\end{abstract}

Keywords: acoustic analysis, dysarthria, affricate

\section{1. 서론}

뇌성마비(cerebral palsy)는 신경 조절의 결함으로 나타나는 운동장애로, 조음 및 발성 기관의 조절에도 문제가 있을 경우에 는 마비말장애(dysarthria)를 동반하기도 한다(as cited in Lee et al.(2013). 마비말장애는 대표적인 발성 장애 중 하나로, 중추 혹 은 말초신경계의 손상으로 말 기제에 대한 근육의 통제가 어려
워져 나타나는 말 운동 장애이다. 이는 신경 운동 조음 장애로, 마비말장애인은 말의 물리적인 산출에 어려움을 겪으며, 말 산 출에 있어 부정확한 조음, 호흡, 발성, 공명, 운율 등의 문제가 존 재한다(Lee et al., 2013). 일반적으로 뇌성마비는 환자의 긴장도에 따라 경직형(spastic), 운동이상형(dyskinetic), 저긴장형(hypotonic), 혼합형(mixed) 등으로 나눌 수 있고, 운동이상형은 불수의운동 형(athetoid), 운동실조형(ataxic), 무정위형(choreiform) 등으로 분

\footnotetext{
* This research is suported by Ministry of Culture, Sports and Tourism and Korea Creative Content Agency(Project Number:R2019080018)

** mchung@snu.ac.kr, Corresponding author

Received 31 May 2021; Revised 11 June 2021; Accepted 12 June 2021

(c) Copyright 2021 Korean Society of Speech Sciences. This is an Open-Access article distributed under the terms of the Creative Commons Attribution NonCommercial License (http://creativecommons.org/licenses/by-nc/4.0) which permits unrestricted non-commercial use, distribution, and reproduction in any medium, provided the original work is properly cited.
} 
류할 수 있다(Ahn, 2018).

마비말장애 발화에 대한 음성학적 연구 중 Byrne(1959)과 Whitehill \& Ciocca(2000)에 따르면 마비말장애 화자들은 모음 보다 자음 발화에 더 어려움을 보이는 것으로 밝혀졌다. 따라서 마비말장애 음성의 연구는 자음 연구가 좀 더 많다고 볼 수 있 다. Kim et al.(2010), Lee et al.(2013), Platt et al.(1980), Whitehill $\& \operatorname{Ciocca}(2000)$ 에 의하면 마비말장애 발화 내의 자음을 조음 방 법에 따라 구분하였을 때 마찰음과 파찰음에서 오류가 가장 빈 번하게 발생한다고 한다. 자음을 조음 위치에 따라 구분하였을 때, 광둥어를 대상으로 한 Whitehill \& Ciocca(2000)와 영어를 대 상으로 한 Kim et al.(2010)에서는 경구개음과 연구개음에서 오 류가 적게 발생한다고 밝힌 반면, 한국어를 대상으로 한 Lee et al.(2013)에서는 경구개음과 연구개음에서 오류가 가장 빈번하 게 발생한다고 밝혔는데, 이는 Kim et al.(2010) 등에서 제시한 조음복잡성 지표로 설명될 수 있다.

조음복잡성(phonetic complexity)은 단어 단위에서 각각의 음 소에 음운 및 음성학적 특징에 따라 체계적으로 가중치를 두어, 해당 단어가 조음 - 음운적으로 얼마나 복잡한가를 수량화한 것이다. 이러한 조음복잡성을 점수로 수량화한 기준표를 조음 복잡성 지표(index of phonetic complexity, IPC)라고 한다(Shin \& $\mathrm{Ha}, 2015)$. 복잡한 음운구조는 단어 내 개별 분절음의 산출을 어 렵게 만들어 전반적인 조음 산출에 영향을 미치는데, 말장애를 지닌 사람들은 음운, 음성학적으로 복잡한 단어를 산출할 때 운 동 프로그래밍을 계획하고 운동을 조절하는 데 어려움을 겪어 조음 오류가 발생할 수 있다(Song et al., 2013). Kim et al.(2010) 에서 조음 방법 또는 조음 위치의 개별적인 요인보다 두 요소가 통합되어 있는 조음복잡성이 마비말장애 발화 내 오류에 영향 을 크게 미친다고 밝혔고, 말더듬을 지닌 아동 및 성인을 대상 으로 한 Lee et al.(2004), 말소리장애 아동을 대상으로 한 Shin \& $\mathrm{Ha}$ (2015)와 마비말장애 성인을 대상으로 한 Song et al.(2013)에 서도 조음복잡성이 높을수록 오류 출현 빈도가 증가한다고 밝 혔다. 따라서 개별 언어의 음운 및 음성학적 특징에 따라 자음 음소를 분류한 조음복잡성 지표에 따라 자음 음소를 분류하고, 조음복잡성이 높은 자음에 초점을 맞추어 마비말장애 발화에 서 발생하는 오류를 분석할 필요가 있다.

Lee et al.(2004)는 Dworzynski \& Howell (2004)의 조음복잡성 지표에 한국어의 발달 특성 및 조음 특성에 관한 연구 결과를 반영하여 한국어의 조음 복잡성 지표를 제시하였고, 이에 따르 면 한국어의 마찰음과 파찰음은 앞에서 살펴 본 연구들의 결과 와 같이 마비말장애 발화에서 오류가 빈번하게 발생하는 음소 임을 볼 수 있다.

마비말장애 한국어 화자의 마찰음 발화를 대상으로 한 연구 로는 경직형 마비말장애 성인을 대상으로 한 Park et al.(2006)과 경직형 마비말장애 아동을 대상으로 한 $\operatorname{Kim} \& \operatorname{Kim}(2013)$ 이 존 재했다. Park et al.(2006)에서는 마찰소음 지속시간, 마찰소음구 간의 최고 주파수, 마찰소음의 강도를 이용하여 한국어의 치경 마찰음을 음향학적으로 분석하였고, $\operatorname{Kim} \& \operatorname{Kim}(2013)$ 에서는 그에 더불어 후행 모음의 길이를 추가적으로 분석하였다. Park et al.(2006)에서는 마찰소음 지속시간은 마비말장애인과 비장 애인 간의 유의한 차이가 없다고 밝힌 반면 $\operatorname{Kim} \& \operatorname{Kim}(2013)$ 에 서는 마비말장애 아동이 비장애 아동보다 짧은 마찰소음 지속 시간을 보였다고 밝혔다. 두 연구 모두 마찰소음구간의 최고 주 파수는 마비말장애인이 비장애인보다 낮았다고 밝혔고, 강도 는 Park et al.(2006)에서는 마비말장애인이 비장애인보다 높은 강도를, $\operatorname{Kim} \& \operatorname{Kim}(2013)$ 에서는 비장애 아동이 마비말장애 아 동보다 높은 강도를 보인다고 밝혔다. $\operatorname{Kim} \& \operatorname{Kim}(2013)$ 에서는 추가적으로 마비말장애 아동의 치경 마찰음 후행 모음의 길이 가 비장애 아동보다 길다고 밝혔다.

한국어의 파찰음은 치경경구개음으로 마찰음보다 조음복잡 성 점수가 높은 음소이고, 치경과 경구개의 경계에서 짧은 폐쇄 후, 경구개쪽으로 혀를 서서히 내리며 순간적인 강한 마찰에너 지가 생성되는 소리로 조음운동적으로 매우 민첩성을 요구하 여 말운동조절능력이 떨어지는 마비말장애인의 경우 더욱 어 려움을 겪는 소리이다. 그러나 마비말장애 한국어 화자의 파찰 음을 대상으로 한 연구는 없었고, 타 언어 중 마비말장애 중국 어 화자의 파찰음 발화를 대상으로 한 연구가 존재했다. Jeng (2000)은 경직형, 불수의운동형, 혼합형 뇌성마비 장애인을 대 상으로 파찰음의 마찰소음 구간의 길이를 분석하였고, Liu et al.(2000)은 경직형, 불수의운동형, 혼합형, 운동실조형 뇌성마 비 장애인을 대상으로 파찰음의 마찰소음 구간의 길이와 파열 실현 정도를, Liu et al.(2016)에서는 경직형, 혼합형 뇌성마비 아 동을 대상으로 그에 더불어 상승 시간을 분석하였다. Jeng (2000)에서는 마비말장애인의 마찰소음구간의 길이가 비장애 인보다 짧다고 밝힌 반면 Liu et al.(2000)과 Liu et al.(2016)에서 는 마비말장애인이 비장애인보다 긴 마찰소음구간의 길이를 보인다고 밝혔다. Liu et al.(2000)과 Liu et al.(2016)에서 모두 파 열 실현 정도는 마비말장애인이 비장애인보다 낮다고 밝혔고, Liu et al.(2016)에서 상승 시간은 마비말장애 아동이 비장애 아 동보다 짧다고 밝혔다. Liu et al.(2000)과 Liu et al.(2016)에서 모 든 분석 요소들에 있어 두 집단 간의 유의한 차이는 존재하지 않는다고 밝혔다. 이러한 연구는 마찰음과 비교하기 위해 한정 된 음향학적 매개변수를 사용하여 파찰음을 분석하였고, 마비 말장애의 유형과 중증도를 분류하지 않아 데이터의 분포가 매 우 다양하게 나타났다는 문제가 있다고 볼 수 있다.

본 연구는 한국어의 마비말장애 음성에서 마찰음과 같이 빈 번한 오류가 발생하는 것으로 알려져 있는 파찰음에 대한 연구 로서, 마비말장애의 유형과 중증도를 한정하고, 파찰음의 특성 에 맞는 음향학적 매개변수를 이용하여 파찰음을 분석하는 것 을 목표로 한다.

\section{2. 연구 방법론}

\section{1. 연구 데이터}

본 연구에는 QoLT(Quality of Life Technology) 기술 개발을 위한 발성장애인용 음성 데이터베이스의 구축 및 보급을 위해 2013.06.01. 2014.05.31. 동안 제작된 음성 데이터베이스인 QoLT_ 
SPEECH_2014 데이터베이스가 사용되었다. QoLT DB는 총 15,069 개 발화로 이루어져 있다. 1차 년도 데이터베이스는 경도중등도 화자 23명의 $\mathrm{APAC}(\mathrm{AP}) 37$ 단어, 기기제어명령어(CW) 100 단어, 한글통화표(KP) 36 단어, 음소균형단어(PBW) 50 단어 발화로 구성되어 있고, 2 차 년도 데이터베이스는 경도-중등도 화자 10 명의 APAC 37 단어, 기기제어명령어 100 단어, 한글통화 표 36단어, VOT 평가용(OT) 9단어 발화로 구성되어 있고, 3차 년도 데이터베이스는 2차 년도와 동일한 경도-중등도 화자 10 명의 확장어휘 $(\mathrm{EX}) 500$ 단어 발화로 구성되어 있다. 해당 데이 터베이스 내의 비장애 화자 및 장애 화자의 음성과 화자 별 $\mathrm{APAC}$ 조음 평가 결과에 따른 조음중증도 정보가 사용되었다.

본 연구는 2012년, 2013년도 조음 평가 결과 경직형 경도-중 등도 마비말장애로 진단된 6 명의 남성 화자를 대상으로 하였고, 녹음 당시 평균 연령은 $34.5 \pm 9.43$ 세였고, 대조군으로는 비장애 인 성인 남성 5명의 발화가 사용되었다. Jongman et al.(2000)은 성별에 따른 스펙트럼 피크의 위치와 스펙트럼 모멘트의 유의 한 차이가 존재한다고 밝혔고, Kong et al.(2014)에서는 젊은 서 울 한국어 화자들에서 파찰음이 어중에 위치할 때/ / / 모음 앞 에서 성별에 따른 스펙트럼 피크 주파수의 유의한 차이가 존재 한다고 밝혔다. 따라서 성별에 의한 영향을 제외하기 위해 남성 화자만을 분석 대상으로 선정하였다. 마비말장애에는 다양한 하위 유형이 존재하는데, 경직형은 그 중 가장 높은 비중을 차 지한다(Lee et al., 2020). 또한 경직형 마비말장애는 신경학적으 로 병소가 확실하게 구분되는데, 이는 상위운동신경(upper motor neuron)의 손상에 기인한다. 상위운동신경이 손상되면 마비된 근육의 긴장도가 증가하여 경직 현상을 보이고, 이를 경직성 불 완전마비라 칭한다(Byeon, 2010). 경직형 마비말장애인은 조음 기관 근육의 지나친 긴장 과다로 인해 특정한 음소들을 조음하 는 데 어려움을 나타내며, 기관들 간에 협응이 좋지 않아 교호 운동 속도나 발화 속도가 정상인에 비해 지나치게 느리게 나타 난다(Lee et al., 2020).

파찰음 발성 유형(평음, 격음, 경음)과 단어 내 파찰음의 위치 (어두 초성, 어중 초성)를 고려하여 QoLT DB 내의 단어 중 파찰 음을 포함하는 단어를 선정하였고, 분석에 사용한 단어는 부록 1 과 같다.

\subsection{1. 청지각적 평가}

마비말장애 화자의 음성 데이터 중, 조음오류가 발생한 데이 터는 제외하고 분석을 진행하였다. 언어치료사 1 명을 측정자로 선정하여 청지각적 분석을 진행하였고, 장애발화를 정조음, 생 략, 대치, 왜곡으로 분류했다. 이를 바탕으로 정조음된 파찰음 발화만을 대상으로 음향학적 분석을 시행하였다. 청지각적 평 가 결과, 총 591 개의 발화 데이터 중, 정조음된 파찰음은 153 개 였다(오류발화 438개). 오류는 크게 대치, 생략, 왜곡, 기타(유성 음화, 파일 내 소리 없음 등)로 나눌 수 있었고, 발생한 오류를 유형에 따라 정리한 결과는 표 1 과 같다.
표 1. 청지각적 평가 결과

Table 1. Auditory-perceptual evaluation results

\begin{tabular}{c|c|c|c|c|c|c}
\hline \multirow{2}{*}{$\begin{array}{c}\text { 파찰음 } \\
\text { 위치 }\end{array}$} & 발성 & \multicolumn{5}{|c}{ 오류 유형 } \\
\cline { 3 - 7 } & 유형 & 정조음 & 대치 & 왜곡 & 생략 & 기타 \\
\hline \multirow{2}{*}{$\begin{array}{c}\text { 어두 } \\
\text { 초성 }\end{array}$} & 평음 & 29 & 72 & 19 & 0 & 0 \\
\cline { 2 - 7 } & 격음 & 26 & 58 & 27 & 3 & 6 \\
\cline { 2 - 7 } & 경음 & 2 & 3 & 1 & 0 & 0 \\
\hline \multirow{2}{*}{$\begin{array}{c}\text { 어중 } \\
\text { 초성 }\end{array}$} & 평음 & 38 & 50 & 30 & 1 & 1 \\
\cline { 2 - 7 } & 격음 & 28 & 63 & 28 & 0 & 1 \\
\cline { 2 - 7 } & 경음 & 30 & 44 & 27 & 1 & 0 \\
\hline
\end{tabular}

2.2. 분석

\subsection{1. 음향학적 분석}

파찰음은 파열음과 마찰음의 조음 연속체로 된 음으로 $(\mathrm{Kim}$ $\& \mathrm{Kim}, 2013)$, 처음에는 폐쇄로 공기를 압축했다가 서서히 마찰 을 일으키며 내놓는 소리이다. 따라서 파찰음에 대한 음향 기술 은 폐쇄 부분(파열음적 성질)과 소음 부분(마찰음적 성질)의 기 술을 포함한다. 마비말장애인 및 비장애인의 마찰음과 파찰음 을 음향학적으로 분석한 선행연구에서 사용한 주요 음향학적 매개변수는 다음과 같다; 마찰음 - 마찰구간 및 기식구간의 길 이, 스펙트럼 모멘트(spectral moments), 파찰음 - 마찰구간 및 묵음구간의 길이, 스펙트럼 모멘트, 파열 실현 정도(Gordon et al., 2002; Hernandez et al., 2019; Jannedy \& Weirich, 2017; Lee, 2017; Li \& Gu, 2015; Tanner et al., 2005; Yang et al., 2018; You et al., 2010). 파찰음의 특징과 선행 연구에서 사용한 주요 음향학 적 매개변수를 종합하여 본 연구에서 선정한 음향학적 매개변 수는 표 2와 같다.

마찰구간 및 기식구간을 정의할 때, 마찰구간과 기식구간이 한국어 파찰음 분석의 하나의 음향적 단서로 기능한다는 선행 연구 결과는 존재하지 않는다(Choi, 2019). 따라서 기식구간과 마찰구간을 합한 구간을 본 연구에서는 ‘마찰구간’이라고 정의 하였다. 파찰음이 어두 초성에 위치하는 경우 $2.5 \mathrm{kHz}$ 이상의 마 찰소음구간이 관찰되는 지점부터 후행 모음의 첫 번째 포먼트 가 시작하는 지점까지, 어중 초성에 위치하는 경우 개방이 시작 되는 수직의 스파이크부터 후행 모음의 첫 번째 포먼트가 시작 하는 지점까지를 마찰구간으로 정의하였다. 파찰음이 어중 초 성에 위치할 때에 명확하게 관찰되는 묵음구간은 선행 모음의 두 번째 포먼트가 끝나는 지점부터 개방이 시작되는 수직의 스 파이크까지로 정의하였다. Praat을 이용하여 분석을 진행하였 고, Praat 상에서 스펙트로그램 이미지를 다음과 같이 설정하였 다; View range: 0 12,000 Hz, Window length: 0.05 s, Dynamic range: $50 \mathrm{~dB}$.

\subsection{2. 통계 분석}

SPSS 통계 프로그램(version 28.0.0.0)을 사용하여 분석을 진 행하였고, 이원혼합분석(two-way mixed ANOVA)을 실시하여 집단, 발성 유형, 집단과 발성 유형의 상호작용 효과가 각 매개 변수에 유의한 영향을 미치는지 확인하였고, 발성 유형에 대해 
서 Bonferroni 사후 검정을 시행하였다. 통계처리는 0.05 유의수 준에서 진행하였다.

표 2. 선정한 음향학적 매개변수

Table 2. Selected acoustic parameters

\begin{tabular}{|c|c|c|}
\hline 분류 & 매개변수 & 성질 \\
\hline \multirow[t]{2}{*}{ 길이 } & 묵음구간의 길이 & $\begin{array}{l}\text { 파열음적 } \\
\text { 성질 }\end{array}$ \\
\hline & 마찰구간의 길이 & \multirow{6}{*}{$\begin{array}{l}\text { 마찰음적 } \\
\text { 성질 }\end{array}$} \\
\hline \multirow{5}{*}{$\begin{array}{l}\text { 스펙트럼 } \\
\text { 모멘트 }\end{array}$} & 중심적률 - 마찰소음 에너지의 강도 & \\
\hline & 왜도 - 마찰소음 에너지의 분포 & \\
\hline & $\begin{array}{l}\text { 첨도 - 마찰소음 에너지 값의 집중 } \\
\text { 또는 분산의 정도 }\end{array}$ & \\
\hline & $\begin{array}{l}\text { 무게중심 - 마찰소음 에너지의 } \\
\text { 순간적인 변화 }\end{array}$ & \\
\hline & $\begin{array}{l}\text { 분산 - 평균으로부터 변량이 떨어져 } \\
\text { 있는 정도 }\end{array}$ & \\
\hline
\end{tabular}

\section{3. 결과}

\section{1. 마찰구간 및 묵음구간의 길이}

마찰구간 및 묵음구간의 길이에 대한 기술통계는 표 3 , 그림 1,2 와 같다.

표 3. 집단 및 발성 유형에 따른 마찰구간 및 묵음구간의 길이 기술통계

Table 3. Descriptive data of frication duration and closure duration by the group and phonation types

\begin{tabular}{|c|c|c|c|c|c|}
\hline & \multicolumn{2}{|c|}{$\begin{array}{c}\text { 마찰구간의 길이 } \\
{[\mathrm{ms}]}\end{array}$} & \multicolumn{2}{|c|}{$\begin{array}{c}\text { 묵음구간의 길이 } \\
{[\mathrm{ms}]}\end{array}$} \\
\hline & & 대조군 & $\begin{array}{l}\text { 마비말 } \\
\text { 장애인 }\end{array}$ & 대조군 & $\begin{array}{l}\text { 마비말 } \\
\text { 장애인 }\end{array}$ \\
\hline \multirow{3}{*}{$\begin{array}{l}\text { 어두 } \\
\text { 초성 }\end{array}$} & 평음 & $\begin{array}{r}98.52 \\
\pm 21.14\end{array}$ & $\begin{array}{r}84.03 \\
\pm 44.28\end{array}$ & & \\
\hline & 격음 & $\begin{array}{l}108.99 \\
\pm 17.78\end{array}$ & $\begin{array}{l}114.07 \\
\pm 46.56\end{array}$ & & \\
\hline & 경음 & $\begin{array}{l}39.80 \\
\pm 8.26\end{array}$ & $\begin{array}{r}66.27 \\
\pm 21.14\end{array}$ & & \\
\hline \multirow{3}{*}{$\begin{array}{l}\text { 어중 } \\
\text { 초성 }\end{array}$} & 평음 & $\begin{array}{r}78.07 \\
\pm 26.79\end{array}$ & $\begin{array}{r}135.61 \\
\pm 108.69\end{array}$ & $\begin{array}{r}24.20 \\
\pm 10.83\end{array}$ & $\begin{array}{r}129.05 \\
\pm 119.09\end{array}$ \\
\hline & 격음 & $\begin{array}{r}98.32 \\
\pm 13.42\end{array}$ & $\begin{array}{l}133.86 \\
\pm 58.60\end{array}$ & $\begin{array}{r}74.32 \\
\pm 11.06\end{array}$ & $\begin{array}{r}170.63 \\
\pm 207.96\end{array}$ \\
\hline & 경음 & $\begin{array}{r}37.14 \\
\pm 10.03\end{array}$ & $\begin{array}{r}81.83 \\
\pm 51.94\end{array}$ & $\begin{array}{r}108.23 \\
\pm 7.34\end{array}$ & $\begin{array}{r}159.53 \\
+108.26\end{array}$ \\
\hline
\end{tabular}

어두 초성 및 어중 초성 파찰음에서 마비말장애인과 대조군 의 마찰구간의 길이를 비교한 결과, 어중 초성에서 집단 간의 유의한 차이가 나타났고 $(F=10.68, p<0.05)$, 마비말장애인이 대 조군보다 유의하게 긴 마찰구간의 길이를 보였다. 어두 초성 $(F=24.23, p<0.05)$ 과 어중 초성 $(F=6.16, p<0.05)$ 에서 발성 유형에 의한 영향이 유의하게 나타났고, Bonferroni 사후 검정을 수행한 결과, 어두 초성에서는 두 집단 모두 격음, 평음, 경음 순으로 긴 마찰구간의 길이를 보였고 그 차이가 유의했다 $(p<0.05)$. 어중 초성에서는 마비말장애인은 평음, 격음, 경음 순으로, 대조군은 격음, 평음, 경음 순으로 긴 마찰구간의 길이를 보였고, 평음과
경음, 격음과 경음 간의 차이가 유의했다 $(p<0.05)$. 어두 초성 $(F=2.88, p>0.05)$ 과 어중 초성 $(F=0.20, p>0.05)$ 모두에서 상호작 용 효과는 유의하지 않았는데, 이는 대조군이 발성 유형에 따라 보이는 마찰구간의 길이의 차이를 마비말장애인도 유사하게 보임을 나타낸다.

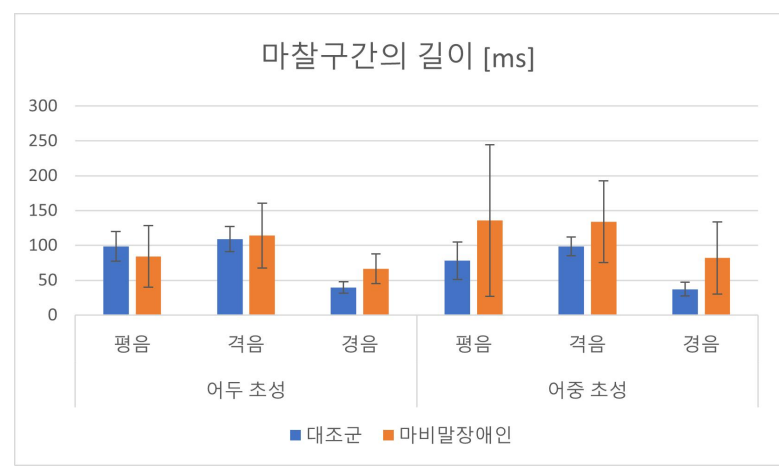

그림 1. 마찰구간의 길이

Figure 1. Frication duration for both speaker groups

어중 초성에 위치하는 파찰음에서 마비말장애인과 대조군의 묵음구간의 길이를 비교한 결과, 집단에 의한 주효과만 나타났 고 $(F=0.22, p<0.05)$, 모든 발성유형에서 마비말장애인이 대조군 보다 유의하게 긴 묵음구간의 길이를 보였다. 대조군은 경음, 격음, 평음 순으로, 마비말장애인은 격음, 경음, 평음 순으로 긴 묵음구간의 길이를 보였는데 발성 유형에 의한 영향은 유의하 지 않았고 $(F=1.594, p>0.05)$, 집단과 발성 유형의 상호작용 효과 도 유의하지 않았다 $(F=0.359, p>0.05)$.

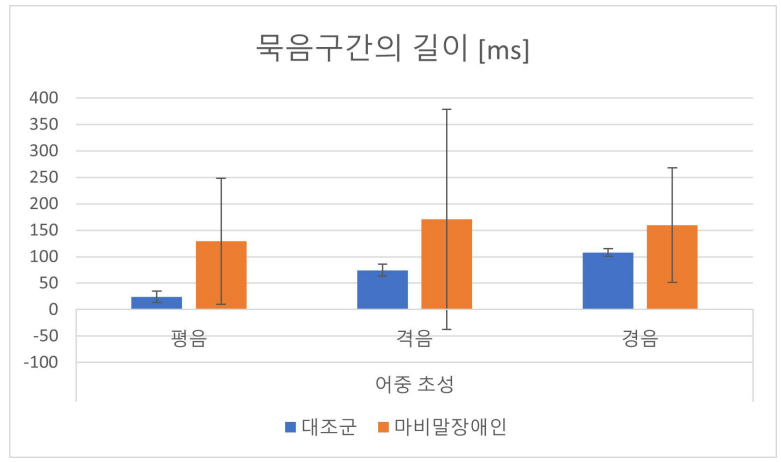

그림 2. 묵음구간의 길이

Figure 2. Closure duration for both speaker groups

3.2. 무게 중심, 분산, 왜도, 첨도, 중심 적률

스펙트럼 모멘트에 대한 기술통계는 표 4, 그림 3 7과 같다.

무게중심의 경우 반복측정분산분석 결과 어두 초성과 어중 초성 모두에서 집단에 의한 유의한 영향은 나타나지 않았고, 발 성 유형(어두: $F=33.39, p<0.05$, 어중: $F=13.28, p<0.05$ )과 상호작 용 효과(어두: $F=16.39, p<0.05$, 어중: $F=4.25, p<0.05$ )의 유의한 영향이 존재했다. Bonferroni 사후 검정 결과 어두 초성에서는 경음, 격음, 평음 순으로 큰 무게중심 값이 나타났고 세 발성 유 
형 간의 차이가 유의했다 $(p<0.05)$. 어중 초성에서는 경음, 평음, 격음 순으로 큰 무게중심 값이 나타났고 세 발성 유형 간의 차 이가 유의했다 $(p<0.05)$. 어두 초성과 어중 초성에서 집단과 발 성 유형의 상호작용 효과가 유의했는데, 이는 마비말장애인이 나타내는 발성 유형에 따른 무게중심 값이 대조군과 동일한 경 향성을 갖지 않음을 보여준다.

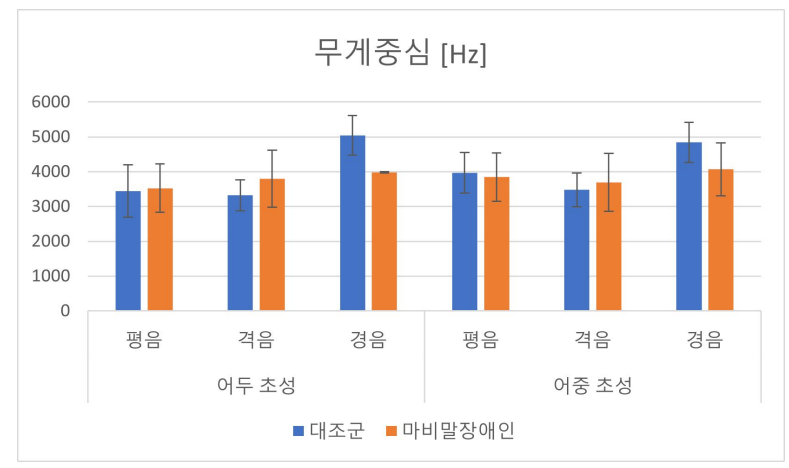

그림 3. 무게중심

Figure 3. Center of gravity for both speaker groups

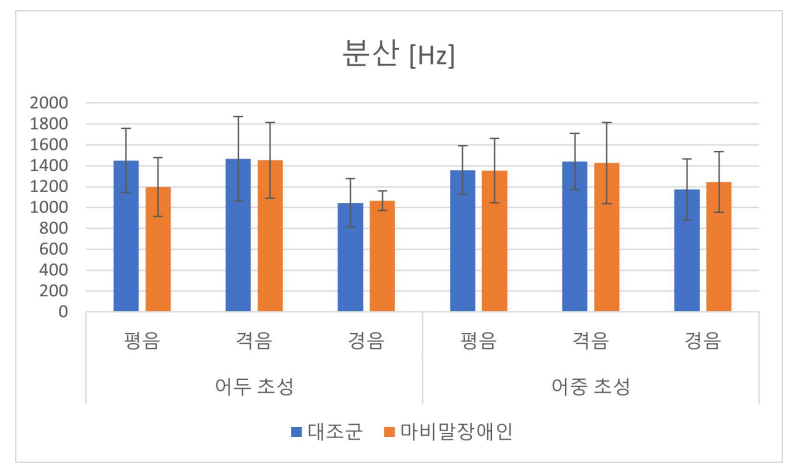

그림 4. 분산

Figure 4. Variance for both speaker groups

분산의 경우 어두 초성과 어중 초성 모두에서 집단(어두: $F=2.717, p>0.05$, 어중: $F=0.095, p>0.05$ )과 상호작용 효과(어두: $F=2.962, p>0.05$, 어중: $F=0.189, p>0.05)$ 에 의한 유의한 영향은 나타나지 않았고, 발성 유형(어두: $F=22.891, p<0.05$, 어중: $F=4.740, p<0.05)$ 에 의한 유의한 영향만 나타났다. Bonferroni 사 후 검정 결과 어두 초성과 어중 초성 모두에서 격음, 평음, 경음 순으로 큰 분산 값이 나타났고 세 발성 유형 간의 차이가 모두 유의했다 $(p<0.05)$. 이는 마비말장애인이 나타내는 발성 유형에 따른 분산 값이 대조군과 유사한 경향성을 지니고, 두 집단 간 의 유의한 차이가 존재하지 않음을 보여준다.

왜도의 경우 어두 초성과 어중 초성 모두에서 집단(어두: $F=27.969, p<0.05$, 어중: $F=11.622, p<0.05)$ 에 의한 유의한 영향 만 존재했고, 발성 유형(어두: $F=2545, p>0.05$, 어중: $F=0.140$, $p>0.05$ )과 상호작용 효과(어두: $F=1.982, p>0.05$, 어중: $F=1.957$, $p>0.05$ )에 의한 유의한 영향은 존재하지 않았다. 모든 환경과 발 성 유형에서 마비말장애인이 대조군보다 유의하게 큰 왜도 값
을 보였다.

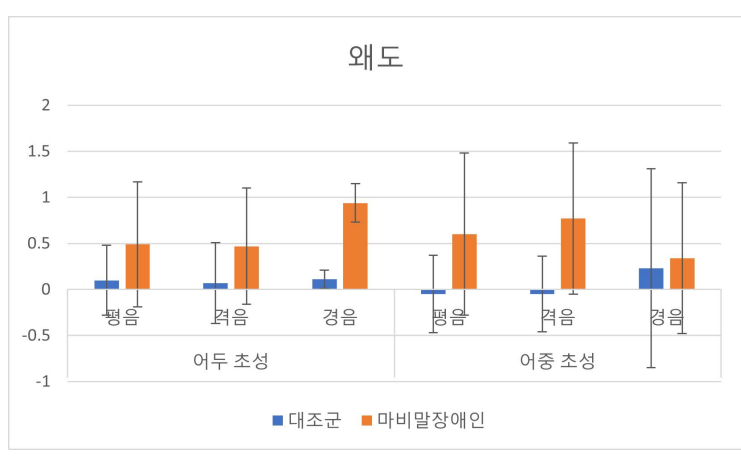

그림 5. 왜도

Figure 5. Skewness for both speaker groups

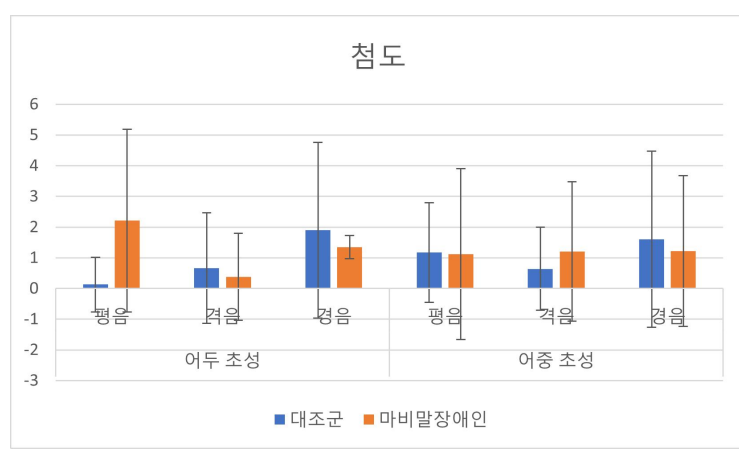

그림 6. 첨도

Figure 6. Kurtosis for both speaker groups

첨도의 경우 어두 초성에서 발성 유형 $(F=3.299, p<0.05)$ 과 상 호작용 $(F=5.651, p<0.05)$ 에 의한 유의한 차이가 나타났다. 어두 초성에서 평음, 경음, 격음 순으로 큰 첨도 값을 보였고 Bonferroni 사후 검정 결과 세 발성 유형에서 모두 그 차이가 유 의했다 $(p<0.05)$. 이는 두 집단 모두 발성 유형에 따라 유의한 차 이가 있는 첨도 값을 나타내고, 마비말장애인이 어두 초성 파찰 음에서 나타내는 첨도 값의 경향성이 대조군과 다름을 보여준 다. 어중 초성에서는 집단 $(F=0.011, p>0.05)$, 발성 유형 $(F=0.377$, $p>0.05)$, 상호작용 효과 $(F=0.380, p>0.05)$ 모두 유의하지 않았으 며, 경음, 격음, 평음 순의 첨도 값을 보였고 평음과 격음, 평음 과 경음 간의 차이가 유의했다 $(p<0.05)$. 어중 초성의 경우 두 집 단이 유사한 경향성을 나타냄을 볼 수 있다. 
표 4. 집단 및 발성 유형에 따른 스펙트럼 모멘트 기술통계

Table 4. Descriptive data of spectral moments by the group and phonation types

\begin{tabular}{|c|c|c|c|c|c|c|c|c|c|c|c|}
\hline & \multicolumn{2}{|c|}{ 무게 중심 [Hz] } & \multicolumn{2}{|c|}{ 분산 [Hz] } & \multicolumn{2}{|c|}{ 왜도 } & \multicolumn{2}{|c|}{ 첨도 } & \multicolumn{2}{|c|}{ 중심 적률 $\left(\times 10^{9}\right)[\mathrm{Hz}]$} \\
\hline & & 대조군 & $\begin{array}{l}\text { 마비말 } \\
\text { 장애인 }\end{array}$ & 대조군 & $\begin{array}{l}\text { 마비말 } \\
\text { 장애인 }\end{array}$ & 대조군 & $\begin{array}{l}\text { 마비말 } \\
\text { 장애인 }\end{array}$ & 대조군 & $\begin{array}{l}\text { 마비말 } \\
\text { 장애인 }\end{array}$ & 대조군 & $\begin{array}{l}\text { 마비말 } \\
\text { 장애인 }\end{array}$ \\
\hline \multirow{3}{*}{$\begin{array}{l}\text { 어두 } \\
\text { 초성 }\end{array}$} & 평음 & $\begin{array}{r}3,448.27 \\
\pm 752.11\end{array}$ & $\begin{array}{r}3,527.73 \\
\pm 690.79\end{array}$ & $\begin{array}{r}1,448.20 \\
\pm 307.42\end{array}$ & $\begin{array}{l}1,195.69 \\
\pm 280.20\end{array}$ & $\begin{array}{r}0.10 \\
\pm 0.38 \\
\end{array}$ & $\begin{array}{r}0.49 \\
\pm 0.68 \\
\end{array}$ & $\begin{array}{r}0.13 \\
\pm 0.89 \\
\end{array}$ & $\begin{array}{r}2.21 \\
\pm 2.98 \\
\end{array}$ & $\begin{array}{r}0.97 \\
\pm 0.92\end{array}$ & $\begin{array}{r}1.30 \\
\pm 0.92 \\
\end{array}$ \\
\hline & 격음 & $\begin{array}{r}3,320.19 \\
\pm 442.11 \\
\end{array}$ & $\begin{array}{r}3,797.34 \\
\pm 822.48 \\
\end{array}$ & $\begin{array}{r}1,465.59 \\
\pm 404.02\end{array}$ & $\begin{array}{l}1,452.67 \\
\pm 363.05\end{array}$ & $\begin{array}{r}0.07 \\
\pm 0.44 \\
\end{array}$ & $\begin{array}{r}0.47 \\
\pm 0.63 \\
\end{array}$ & $\begin{array}{r}0.66 \\
\pm 1.80 \\
\end{array}$ & $\begin{array}{r}0.38 \\
\pm 1.42 \\
\end{array}$ & $\begin{array}{r}1.32 \\
\pm 1.16\end{array}$ & $\begin{array}{r}1.79 \\
\pm 1.40\end{array}$ \\
\hline & 경음 & $\begin{array}{r}5,040.07 \\
\pm 570.39\end{array}$ & $\begin{array}{r}3,978.06 \\
\pm 19.59\end{array}$ & $\begin{array}{r}1,043.87 \\
\pm 230.71\end{array}$ & $\begin{array}{r}1,063.03 \\
\pm 94.30\end{array}$ & $\begin{array}{r}0.11 \\
\pm 0.10 \\
\end{array}$ & $\begin{array}{r}0.94 \\
\pm 0.21 \\
\end{array}$ & $\begin{array}{r}1.90 \\
\pm 2.86 \\
\end{array}$ & $\begin{array}{r}1.35 \\
\pm 0.38 \\
\end{array}$ & $\begin{array}{r}0.80 \\
\pm 0.62\end{array}$ & $\begin{array}{r}1.08 \\
\pm 0.39 \\
\end{array}$ \\
\hline \multirow{3}{*}{$\begin{array}{l}\text { 어중 } \\
\text { 초성 }\end{array}$} & 평음 & $\begin{array}{r}3,969.32 \\
\pm 586.97 \\
\end{array}$ & $\begin{array}{r}3,847.38 \\
\pm 692.54\end{array}$ & $\begin{array}{r}1,356.75 \\
\pm 234.64\end{array}$ & $\begin{array}{l}1,352.81 \\
\pm 309.07\end{array}$ & $\begin{array}{l}-0.05 \\
\pm 0.42\end{array}$ & $\begin{array}{r}0.60 \\
\pm 0.88 \\
\end{array}$ & $\begin{array}{r}1.17 \\
\pm 1.62 \\
\end{array}$ & $\begin{array}{r}1.12 \\
\pm 2.78 \\
\end{array}$ & $\begin{array}{r}0.91 \\
\pm 0.66 \\
\end{array}$ & $\begin{array}{r}1.88 \\
\pm 1.96 \\
\end{array}$ \\
\hline & 격음 & $\begin{array}{r}3,479.43 \\
\pm 485.10\end{array}$ & $\begin{array}{r}3,688.68 \\
\pm 832.62\end{array}$ & $\begin{array}{r}1,438.47 \\
\pm 268.70\end{array}$ & $\begin{array}{l}1,427.25 \\
\pm 389.00\end{array}$ & $\begin{array}{l}-0.05 \\
\pm 0.41\end{array}$ & $\begin{array}{r}0.77 \\
\pm 0.82 \\
\end{array}$ & $\begin{array}{r}0.64 \\
\pm 1.35 \\
\end{array}$ & $\begin{array}{r}1.21 \\
\pm 2.27 \\
\end{array}$ & $\begin{array}{r}1.06 \\
\pm 1.05 \\
\end{array}$ & $\begin{array}{r}2.86 \\
\pm 2.49 \\
\end{array}$ \\
\hline & 경음 & $\begin{array}{r}4,840.90 \\
\pm 574.29 \\
\end{array}$ & $\begin{array}{r}4,069.99 \\
\pm 760.87 \\
\end{array}$ & $\begin{array}{r}1,172.12 \\
\pm 291.77\end{array}$ & $\begin{array}{l}1,243.32 \\
\pm 289.37\end{array}$ & $\begin{array}{r}0.23 \\
\pm 1.08 \\
\end{array}$ & $\begin{array}{r}0.34 \\
\pm 0.82 \\
\end{array}$ & $\begin{array}{r}1.60 \\
\pm 2.87 \\
\end{array}$ & $\begin{array}{r}1.22 \\
\pm 2.45 \\
\end{array}$ & $\begin{array}{r}1.18 \\
\pm 1.11 \\
\end{array}$ & $\begin{array}{r}1.27 \\
\pm 1.07 \\
\end{array}$ \\
\hline
\end{tabular}

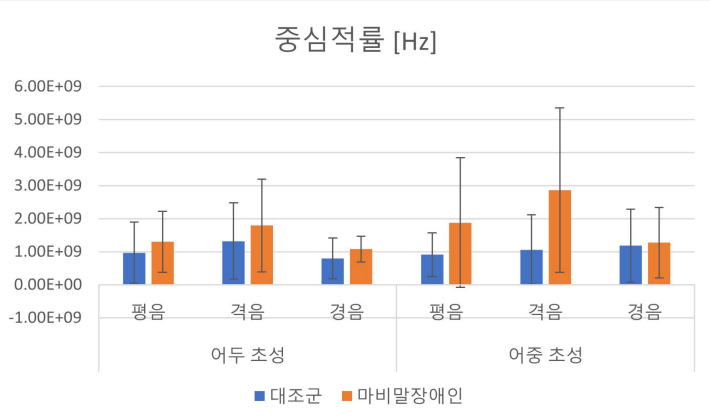

그림 7. 중심적률

Figure 7. Central moment for both speaker groups

중심적률의 경우 어두 초성에서는 집단 $(F=4.077, p<0.05)$ 과 발성 유형 $(F=4.149, p<0.05)$ 에 의한 유의한 영향이 나타났고, 상 호작용 효과 $(F=0.106, p>0.05)$ 는 유의하지 않았다. 마비말장애 인이 대조군보다 유의하게 큰 중심적률 값을 보였고, 두 집단 모두 격음, 평음, 경음 순으로 큰 중심적률 값을 보였고, Bonferroni 사후 검정 결과 세 발성 유형 간의 차이는 모두 유의 했다. 어중 초성의 경우는 집단 $(F=7.320, p<0.05)$ 에 의한 유의한 효과만 나타났고, 모든 발성 유형에서 마비말장애인이 대조군 보다 유의하게 큰 무게중심 값을 보였다.

\section{4. 고찰}

본 연구에서는 경직형 마비말장애인이 산출한 파찰음을 한 국어의 파찰음의 음향학적 특성을 반영하는 마찰구간의 길이, 묵음구간의 길이, 무게중심, 분산, 왜도, 첨도, 중심적률의 매개 변수를 사용하여 분석하고, 대조군과 비교하였다.

마비말장애인과 대조군의 마찰구간의 길이를 비교한 결과, 어두 초성에서는 평음을 제외하고 마비말장애인이 대조군보다 긴 마찰구간의 길이를 보였으나 그 차이는 유의하지 않았고, 어 중 초성에서는 마비말장애인이 대조군보다 유의하게 긴 마찰 구간의 길이를 보였다. 이는 중국어 마비말장애 화자를 대상으 로 진행한 Liu et al.(2000), Liu et al.(2016)의 결과와 일부 일치하
고, Jeng(2000)과는 일치하지 않는 결과이다. 경직형 마비말장 애의 가장 큰 특징은 느린 말속도인데, Jeng(2000)에서는 발화 전체에서는 장애인이 비장애인보다 느린 말속도를 갖지만, 각 분절음들의 길이는 분절음의 유형에 영향을 받고, 자음의 산출 은 모음보다 더 많은 조음기관의 협응과 근지구력을 요구하기 에 마비말장애인이 자음 산출에 어려움을 격는다고 밝혔다. 그 러나 Jeng(2000)은 전반적인 마비말장애의 유형을 대상으로 위 와 같은 결론을 내렸기에, 본 연구에서 대상으로 삼은 경직형 마비말장애에서는 분절적인 요소보다 해당 유형의 특징인 느 린 말속도가 마찰구간의 길이에 영향을 더 크게 미쳤다고 볼 수 있다.

어두 초성과 어중 초성에서 발성 유형에 의한 유의한 차이가 존재했고, 집단과 발성 유형의 상호작용 효과는 유의하지 않게 나타났는데, 이를 통해 마비말장애인이 대조군과 유사하게 발 성 유형에 따라 변별적으로 음을 산출할 수 있고, 대조군과 유 사하게 발성 유형에 따른 마찰구간의 길이 차이를 조절할 수 있 음을 확인할 수 있다.

또한 모든 발성 유형에서 마비말장애인은 어중 초성 파찰음 의 마찰구간의 길이가 어두 초성 파찰음보다 길게 나타난 반면 대조군은 어두 초성 파찰음의 마찰구간의 길이가 어중 초성 파 찰음보다 길게 나타났다. 이는 경직형 마비말장애 아동이 산출 한 마찰음을 연구한 $\operatorname{Kim} \& \operatorname{Kim}(2013)$ 에서 장애 아동과 비장애 아동 모두 평음의 마찰구간의 길이는 어두 위치가 어중 위치보 다 길었고, 경음의 마찰구간의 길이는 어중 위치가 어두 위치보 다 길었다는 결과와 상충한다. 본 연구의 결과에 의하면 파찰음 의 마찰구간의 길이는 마찰음과 달리 발성 유형보다 파찰음이 단어 내에서 차지하는 위치에 영향을 크게 받는다는 결론을 내 릴 수 있다.

마비말장애인과 대조군의 묵음 구간의 길이를 비교한 결과, 집단에 의한 주효과만 나타났고 모든 발성 유형에서 마비말장 애인이 대조군보다 유의하게 긴 묵음 구간의 길이를 보였으며, 발성 유형과 상호작용 효과에 의한 영향은 유의하지 않았다. $\operatorname{Kim}(2006)$ 은 마비말장애인은 기식성보다 긴장성을 위한 후두 및 조음 기관의 협착 운동에서 시간 조절 능력에 어려움을 보인 
다고 밝혔다. 또한 경직형 마비말장애의 특징인 과긴장성이 긴 장을 요구하는 파열에 영향을 미치고, 느린 말속도가 묵음구간 의 길이에 영향을 미쳤을 것이다. 따라서 마비말장애인이 파열 을 위한 긴장에 어려움을 겪고 과긴장성으로 인해 발성 유형에 따른 긴장 정도를 조절하는 데 어려움이 존재하여 발성 유형에 따른 묵음구간의 길이의 차이가 유의하게 나타나지 않았고, 과 긴장성과 느린 말속도로 인해 대조군보다 유의하게 긴 묵음구 간의 길이를 나타냈다고 볼 수 있다. 더불어, 묵음구간의 길이 가 경직형 마비말장애인을 구별하는 하나의 음향학적 매개변 수로 기능할 수 있음을 보여준다.

무게중심의 경우 어두 초성 및 어중 초성 경음에서 마비말장 애인이 대조군보다 낮은 무게중심 값을 가졌다. 파찰음의 마찰 운동은 구강 내 기류가 빠르게 통과하여 생성된 순간적이고 강 한 마찰 에너지를 필요로 한다. 순간적인 마찰 에너지가 생성되 면 마찰구간에 강한 에너지가 집중되고, 무게중심 값이 증가하 게 된다. Park et al.(2006)은 마비말장애인이 마찰음 산출 시에 설단이 아닌 설등이나 설근을 구개에 협착시키거나, 혹은 설단 을 구개에 협착시키더라도 협착 후 음을 산출하는 동안 혀를 적 절하게 유지하지 못한다고 밝혔다. 또한 경음은 세 발성 유형 중 가장 강한 순간적인 마찰 에너지를 요구하는 발성 유형이다. 따라서 경음의 경우 마비말장애인이 마찰을 위한 조음기관의 운동을 적절히 수행하지 못하고, 그로 인해 순간적인 에너지 집 중에 어려움을 격어 대조군보다 낮은 무게중심 값을 나타냈다 는 것을 알 수 있다. 또한 경직형 마비말장애의 특징인 과긴장 성으로 인해 마비말장애인이 파찰음을 조음할 때 전반적으로 강한 에너지를 사용하여 순간적이고 강한 에너지를 사용하는 대조군보다 낮은 무게중심 값을 나타냈다고 볼 수 있다.

어두 및 어중 초성 격음에서는 마비말장애인이 대조군보다 높은 무게중심 값을 보였는데, 기식성이 있는 파찰음을 조음할 때에는 마비말장애인이 순간적인 마찰에너지를 사용할 수 있 으나 대조군보다 강한 에너지를 사용함을 시사한다. 따라서 마 비말장애인이 발성 유형에 따라 긴장 정도를 조절할 수 있으나 기식성 혹은 강한 에너지를 필요로 하는 파찰음을 조음하는 데 평음보다 어려움을 겪고, 대조군과 동일한 경향성을 지니지 않 음을 확인할 수 있다.

분산은 에너지의 평균으로부터 변량이 떨어져 있는 정도를 나타내는데, 마비말장애는 동일한 화자 내에서도 발화 시마다 다양한 발화 특성이 나타나는 성질을 지니고 있기에 마비말장 애인의 분산 값이 대조군보다 유의하게 크게 나타날 것으로 예 상하였으나 연구 결과 어두 초성 경음과 어중 초성 경음을 제외 하고 마비말장애인이 대조군보다 낮은 분산 값을 보였고, 집단 에 의한 영향은 유의하지 않았으며 발성 유형에 의한 유의한 영 향만 존재했다. 세 발성 유형 중 가장 강한 긴장을 필요로 하는 경음에서 마비말장애인의 분산 값이 대조군보다 높게 나타나 경직형 마비말장애인은 긴장을 많이 요구하는 음소일수록 일 관성 있는 조음에 어려움을 겪음을 확인할 수 있다.

왜도의 경우 집단에 의한 유의한 영향이 존재했고, 마비말장 애인이 대조군보다 유의하게 큰 왜도 값을 보였다. 이는 마비말
장애인들이 산출한 파찰음의 에너지 분포가 평균을 중심으로 대조군보다 더 치우쳐 있음을 의미하고, 양의 왜도는 마찰소음 의 에너지가 낮은 주파수 대역에 집중되어 있음을 보여준다 (Jongman et al., 2000). 따라서 마비말장애인이 산출한 파찰음의 마찰소음의 에너지는 대조군보다 낮은 주파수 대역에 집중되 어 있음을 나타내고, 마찰소음구간의 왜도는 장애인과 비장애 인을 구별하는 하나의 음향학적 매개변수로 기능한다는 결론 을 내릴 수 있다.

첨도의 경우 어두 초성에서 발성 유형과 상호작용 효과에 의 한 영향이 유의하게 나타났는데, 평음의 첨도 값이 격음, 경음 보다 유의하게 높았다 $(p<0.05)$. 첨도 값이 높으면 데이터의 분 포에 이상치가 다수 존재함을 의미하는데, 마비말장애인의 마 찰구간의 길이, 무게중심, 분산 데이터에서 어두 초성 평음 파 찰음에서 타 환경 및 발성 유형과 다른 경향성을 지니는 결과가 발견되었다. 따라서 마비말장애인의 어두 초성 평음 발화에 이 상치가 다수 존재하고, 이를 추가적으로 분석해야 할 필요성을 시사한다.

중심적률은 파찰음을 조음할 때 마찰소음 에너지의 강도를 나타내는 지표인데, 모든 환경과 발성 유형에서 마비말장애인 이 대조군보다 유의하게 높은 중심적률 값을 보였다. 이는 마비 말장애인이 파찰음을 조음할 때 전반적으로 대조군보다 강한 에너지를 사용하여 조음한다는 것을 보여주고, 이는 경직형 마 비말장애의 특징인 과긴장성으로 인한 결과로 볼 수 있다. 즉, 마비말장애인이 파찰음 조음 시 센 기류와 함께 강한 에너지, 긴장을 동반하기 때문에 제대로 된 마찰소음 생성이 어렵고, 구 강 내 혀의 긴장 및 음을 산출할 때 혀를 적절하게 유지하기 못 하기 때문에 민첩하고 순간적인 마찰이 어려워 정확한 마찰을 수행하는 데 어려움을 겪는다고 볼 수 있다. 더불어 중심적률이 경직형 마비말장애인을 구별하는 하나의 음향학적 매개변수로 기능할 수 있음을 보여준다.

\section{5. 결론}

본 연구는 경직형 마비말장애 성인이 산출한 파찰음을 음향 학적으로 분석하였고, 그 결과 다음과 같은 결론을 얻었다.

첫째, 어중 초성 파찰음에서 마비말장애인이 유의하게 긴 마 찰구간의 길이를 보였다.

둘째, 마비말장애인이 유의하게 긴 묵음구간의 길이를 보였다.

셋째, 무게중심의 경우 두 집단 간의 유의한 차이가 존재하지 않았다.

넷째, 마비말장애인이 유의하게 큰 왜도 값을 보였다.

다섯째, 마비말장애인이 유의하게 큰 중심적률 값을 보였다.

본 연구의 한계는 첫째, 선행, 후행 모음을 고려하지 않았다 는 것이다. Nam \& Yi(2010)에서 기능적 조음장애아동은 평 . 경 마찰음 모두에서 마찰구간의 길이가 어음 환경과 상관 없이 모 음의 개구도에 영향을 받는다고 밝혔다. 이처럼 모음 환경이 자 음에 영향을 미치기 때문에, 선행, 후행 모음을 통일하여 어음 목록을 설계하면 보다 더 정확한 실험 결과를 얻을 수 있을 것 
이다. 둘째로 한정된 중증도를 지니는 마비말장애인을 대상으 로 연구를 진행하였다는 것이다. 후속 연구에서 다양한 중증도 를 지니는 마비말장애인을 대상으로 연구를 진행하면 중증도 에 따라 분석 요소들이 어떻게 달라지고, 어떠한 경향성을 지니 는지를 파악할 수 있을 것이다.

기존 마비말장애인의 파찰음 발화 연구는 파찰음과 유사한 특성을 지닌 마찰음과 비교하는 데에 그쳤고, 한정적인 음향학 적 매개변수만을 이용하여 진행되었다. 본 연구는 한국어의 파 찰음의 특성에 맞는 음향학적 매개변수를 제시하고, 그를 이용 하여 파찰음을 분석하였다. 또한 마비말장애인과 대조군이 산 출한 파찰음의 차이를 규명하여 마비말장애인의 파찰음 발화 특성을 정의하였고, 두 집단을 구별할 수 있는 음향학적 매개변 수를 제시하였다는 데에 의의가 있다.

\section{References}

Ahn, M. (2018). Types of cerebral palsy [Web log post]. Retrieved from https://hworld.org/385

Byeon, H. W. (2010). Comparing the acoustic character of diphthong production between flaccid dysarthria and spastic dysarthria. Communication Sciences \& Disorders, 15(1), 66-78.

Byrne, M. C. (1959). Speech and language development of athetoid and spastic children. Journal of Speech and Hearing Disorders, 24(3), 231-240.

Chang, C. B. (2008). The acoustics of Korean fricatives revisited. Harvard Studies in Korean Linguistics, 12, 137-150.

Choi, Y. (2019). Acoustics properties of Korean affricative produced by Russian speakers. Korean Language Research, (51), 215-252.

Dworzynski, K., \& Howell, P. (2004). Predicting stuttering from phonetic complexity in German. Journal of fluency disorders, 29(2), 149-173.

Gordon, M., Barthmaier, P., \& Sands, K. (2002). A cross-linguistic acoustic study of voiceless fricatives. Journal of the International Phonetic Association, 32(2), 141-174.

Hernandez, A., Lee, H., \& Chung, M. (2019). Acoustic analysis of fricatives in dysarthric speakers with cerebral palsy. Phonetics and Speech Sciences, 11(3), 23-29.

Jannedy, S., \& Weirich, M. (2017). Spectral moments vs discrete cosine transformation coefficients: Evaluation of acoustic measures distinguishing two merging German fricatives. The Journal of the Acoustical Society of America, 142(1), 395-405.

Jeng, J. Y. (2000). Intelligibility and acoustic characteristics of the dysarthria in Mandarin speakers with cerebral palsy (Doctoral dissertation). The University of Wisconsin-Madison, Madison, WI.

Jongman, A., Wayland, R., \& Wong, S. (2000). Acoustic characteristics of English fricatives. The Journal of the Acoustical Society of America, 108(3), 1252-1263.
Kim, H. (2006). Acoustic analysis of plosive generation in patients with dysarthria (Master's thesis). Yonsei University, Seoul, Korea.

Kim, H., Martin, K., Hasegawa-Johnson, M., \& Perlman, A. (2010). Frequency of consonant articulation errors in dysarthric speech. Clinical Linguistics \& Phonetics, 24(10), 759-770.

Kim, S., \& Kim, H. (2013). Acoustic characteristics of Korean alveolar sibilant 's', 's' according to phonetic contexts of children with cerebral palsy. Phonetics and Speech Sciences, 5(2), 3-10.

Kong, E. J., Kang, S., \& Seo, M. (2014). Gender difference in the affricate productions of young Seoul Korean speakers. The Journal of the Acoustical Society of America, 136(4), EL329-EL335.

Lee, E. J., Han, J. S., \& Sim, H. S. (2004). The effects of the phonetic complexity on the disfluencies and the articulation errors of people who stutter. Communication Sciences \& Disorders, 9(3), 139-156.

Lee, G. (2017). Examination of aspiration in Korean fricatives and affricates. Phonetics and Speech Sciences, 9(2), 31-38.

Lee, J. S., Lee, J. Y., \& Kim, S. H. (2020). Effect of articulation abilities on the articulator strength training by IOPI of spasticity dysarthric speech. Therapeutic Science for Rehabilitation, 9(1), 91-99.

Lee, Y., Sung, J. E., \& Sim, H. S. (2013). Consonant confusions matrices in adults with dysarthria associated with cerebral palsy. Phonetics and Speech Sciences, 5(1), 47-54.

Li, S., \& Gu, W. (2015, September). Acoustic analysis of Mandarin affricates. Proceedings of the 16th Annual Conference of the International Speech Communication Association. Dresden, Germany.

Liu, C., Chen, L. M., Lin, Y. C., Cheng, C. F., \& Chang, H. C. (2016, October). Speech intelligibility and the production of fricative and affricate among Mandarin-speaking children with cerebral palsy. Proceedings of the 28th Conference on Computational Linguistics and Speech Processing (ROCLING 2016) (pp. 153-163). Tainan, Taiwan.

Liu, H. M., Tseng, C. H., \& Tsao, F. M. (2000). Perceptual and acoustic analysis of speech intelligibility in Mandarin-speaking young adults with cerebral palsy. Clinical Linguistics \& Phonetics, 14(6), 447-464.

Nam, J. H., \& Yi, B. W. (2010). Acoustic properties of fricatives produced by children with functional articulation disorder. Phonetics and Speech Sciences, 2(4), 93-100.

Park, H. J., Shin, H. J., Jeong, O. R., \& Seok, D. I. (2006). An acoustical and perceptual study of /s/ in the speech of dysarthric speakers. Journal of Special Education \& Rehabilitation Science, 45(1), 187-202.

Platt, L. J., Andrews, G., \& Howie, P. M. (1980). Dysarthria of adult cerebral palsy: II. Phonemic analysis of articulation errors. Journal of Speech, Language, and Hearing Research, 23(1), 41-55.

Shin, G. E., \& Ha, J. W. (2015). The effects of phonetic complexity on the disfluency and articulation errors of children with speech sound 
disorders. Journal of Speech-Language \& Hearing Disorders, 24(1), 91-102.

Song, H. N., Lee, Y., Sim, H. S., \& Sung, J. E. (2013). Effects of phonetic complexity and articulatory severity on percentage of correct consonant and speech intelligibility in adults with dysarthria. Phonetics and Speech Sciences, 5(1), 39-46.

Tanner, K., Roy, N., Ash, A., \& Buder, E. H. (2005). Spectral moments of the long-term average spectrum: Sensitive indices of voice change after therapy? Journal of Voice, 19(2), 211-222.

Whitehill, T. L., \& Ciocca, V. (2000). Speech errors in Cantonese speaking adults with cerebral palsy. Clinical Linguistics \& Phonetics, 14(2), 111-130.

Yang, M., Choi, Y., Kim, E. Y., \& Yoo, H. J. (2018). Acousticphonetic characteristics of fricatives distortion in functional articulation disorders. Phonetics and Speech Sciences, 10(4), 127-134.

You, Y. S., Jang, S. J., Bak, S. J., \& Choi, Y. L. (2010). Acoustic analysis of the differences of fricatives and affricates between normal children and cleft palate children. The Journal of the Korea Contents Association, 10(5), 285-295.

\section{- 문지현 (Jihyun Mun)}

서울대학교 언어학과 석박통합과정

서울시 관악구 관악로 1

Tel: 02-880-6164

Email: jhhh_1202@snu.ac.kr

관심분야: 음성인식, 음성언어처리, 언어 장애

\section{- 김선희 (Sunhee Kim)}

서울대학교 불어교육과 교수

서울시 관악구 관악로 1

Tel: 02-880-7693

Email: sunhim@snu.ac.kr

관심분야: 프랑스어 음성학, 음성언어처리

- 정민화 (Minhwa Chung) 교신저자

서울대학교 언어학과 교수

서울시 관악구 관악로 1

Tel: 02-880-9195

Email: mchung@snu.ac.kr

관심분야: 음성인식, 음성언어처리, 컴퓨터 기반 언어교육 


\section{부록 1. 분석에 사용한 단어}

\begin{tabular}{|c|c|c|c|c|c|c|c|c|c|c|c|}
\hline \multicolumn{6}{|c|}{ 어두 초성 } & \multicolumn{6}{|c|}{ 어중 초성 } \\
\hline \multicolumn{2}{|c|}{ 평음 } & \multicolumn{2}{|c|}{ 격음 } & \multicolumn{2}{|c|}{ 경음 } & \multicolumn{2}{|c|}{ 평음 } & \multicolumn{2}{|c|}{ 격음 } & \multicolumn{2}{|c|}{ 경음 } \\
\hline 파일명 & 단어 & 파일명 & 단어 & 파일명 & 단어 & 파일명 & 단어 & 파일명 & 단어 & 파일명 & 단어 \\
\hline AP ?014 & 장갑 & AP ?008 & 책 & AP ?031 & 찢어요 & AP ?013 & 모자 & AP ?012 & 단추 & CW ?008 & 네 번째 \\
\hline CW_?078 & 작게 & AP_?017 & 침대 & & & AP_?018 & 화장실 & CW_?006 & 김치 & CW_?011 & 다섯 번째 \\
\hline CW_?079 & 재생 & CW_?088 & 채널 & & & CW_?001 & 거절 & CW_?019 & 마침표 & CW_?016 & 두 번째 \\
\hline CW ?080 & 저장 & CW ?089 & 첫번째 & & & CW ?043 & 시작 & CW ?035 & 사진촬영 & CW ?034 & \begin{tabular}{|c|} 
사진찍기 \\
\end{tabular} \\
\hline CW_?081 & 전송 & CW_?090 & 축소 & & & CW_?080 & 저장 & CW_?082 & 전체 & CW_?039 & 세 번째 \\
\hline CW_?082 & 전체 & CW_?092 & 치즈 & & & CW_?086 & 정지 & EX_0026 & 위치알림 & CW_?049 & 아홉 번째 \\
\hline CW_?083 & 전화걸기 & CW_?093 & 칠번 & & & CW_?092 & 치즈 & EX_0027 & 위치 & CW_?051 & 여덟 번째 \\
\hline CW_?084 & 전화받기 & KP_?010 & 치마 & & & KP_?003 & 도라지 & EX_0043 & 기차 & CW_?052 & 여섯 번째 \\
\hline CW_?085 & 정열 & KP_?033 & 칠 & & & KP_?006 & 바가지 & EX_0066 & 좌측 & CW_?053 & 열 번째 \\
\hline CW_?086 & 정지 & EX_0015 & 참새 & & & KP_?015 & 아버지 & EX_0071 & 우측 & CW_?056 & 오른쪽 \\
\hline CW_?087 & 종료 & EX_0047 & 찾기 & & & KP_?019 & 오징어 & EX_0173 & 으차차 & CW_?058 & 왼쪽 \\
\hline KP_?009 & 지게 & EX_0083 & 친구 & & & KP_?020 & 요지경 & EX_0298 & 유치원 & CW_?075 & 일곱 번째 \\
\hline EX_0001 & 전화 & EX_0084 & 치타 & & & EX_0006 & 메시지 & EX_0307 & 규칙적 & CW_?089 & 첫 번째 \\
\hline EX_0005 & 자라 & EX_0133 & 치약 & & & EX_0061 & 두더지 & EX_0316 & 유채꽃 & EX_0187 & 둘째 \\
\hline EX_0025 & 제비 & EX_0134 & 차표 & & & EX_0082 & 정정 & EX_0340 & 정치권 & EX_0260 & 된장찌개 \\
\hline EX_0028 & 자리 & EX_0135 & 차이 & & & EX_0085 & 오미자 & EX_0360 & 후춧가루 & EX_0466 & 양쪽 \\
\hline EX_0065 & 지렁이 & EX_0202 & 칠뜨기 & & & EX_0086 & 요전 & EX_0396 & 동창회 & EX_0499 & 뒤쪽 \\
\hline EX_0080 & 자두 & EX_0203 & 칠판 & & & EX_0127 & 아줌마 & EX_0406 & 양배추 & & \\
\hline EX_0082 & 정정 & EX_0204 & 칠면조 & & & EX_0139 & 타조 & EX_0421 & 고춧가루 & & \\
\hline EX_0097 & 전달 & EX_0255 & 체육관 & & & EX_0140 & 타잔 & EX_0425 & 휠체어 & & \\
\hline
\end{tabular}




\title{
뇌성마비 마비말장애 성인의 파찰음 실현 양상 분석*
}

\author{
문 지 현 ${ }^{1}$ 김 선 희 ${ }^{2}$ 정 민 화 ${ }^{1}$ \\ ${ }^{1}$ 서울대학교 언어학과, ${ }^{2}$ 서울대학교 불어교육과
}

\begin{abstract}
국문초록
본 연구는 경직형 경도-중등도 뇌성마비 마비말장애 성인이 산출한 한국어 파찰음의 음향학적인 특징을 분석한다. 한국어의 마찰음과 파찰음은 조음오류가 빈번하게 발생하는 자음인 데, 기존 연구들은 마찰음에만 집중했다. 따라 서 본 연구에서는 마비말장애 화자가 산출한 파찰음을 음향학적으로 분석하고자 한다. QoLT_SPEECH_2014 데이 터베이스 내에서 파찰음 $/ \mathrm{tc}, \mathrm{tc}^{\mathrm{h}},{ }_{n} \mathrm{t} /$ 이 어두 초성 및 어중 초성에 위치하는 단어를 선정하여 경도-중등도 경직형 장 애 남성 화자 6 명과 비장애 남성 화자 5 명의 발화 데이터를 분석에 사용하였다. 한국어의 파찰음의 특성을 고려하 여 파찰음의 음향학적 특징을 나타내는 매개변수를 선정하여 분석을 시행하였다: 마찰구간의 길이, 묵음 구간의 길이, 무게중심, 분산, 왜도, 첨도, 중심적률. 분석 결과는 다음과 같다: 1) 어중 초성 파찰음에서 마비말장애인이 유 의하게 긴 마찰구간의 길이를 보였다, 2) 마비말장애인이 유의하게 긴 묵음 구간의 길이를 보였다, 3) 무게중심의 경우 두 집단 간의 유의한 차이가 존재하지 않았다, 4) 마비말장애인이 유의하게 큰 왜도 값을 보였다, 5) 마비말장 애인이 유의하게 큰 중심적률 값을 보였다. 본 연구는 마비말장애인이 산출한 파찰음의 특성을 분석하고, 비장애 인이 산출한 파찰음과의 차이를 밝혔다.
\end{abstract}

핵심어: 마비말장애, 음성학, 파찰음

\section{참고문헌}

김숙희, 김현기(2013). 뇌성마비 아동의 음성 환경에 따른 치경 마찰음 ‘ㅅ', ‘’의 음향학적 특성. 말소리와 음성과학, 5(2), 3-10.

김현승(2006). 마비말장애 환자의 파열음 산출의 음향학적 분 석. 연세대학교 석사학위논문.

남정훈, 이봉원(2010). 기능적 조음장애아동이 산출한 마찰음의 음향음성학적 특성. 말소리와 음성과학, 2(4), 93-100.

박지현(2009). 경직형과 이완형 마비말장애의조음음운오류: 읽 기 과제에서. 연세대학교 석사학위논문.

박희정, 신혜정, 정옥란, 석동일(2006). 마비성 구어장애인들의 마찰음/s/에 대한 음향학적 - 청지각적 연구. 특수교육재활과 학연구, 45(1), 187-202.

송한내, 이영미, 심현섭, 성지은(2013). 조음복잡성 및 조음중증 도에 따른 마비말장애인의 자음정확도와 말명료도. 말소리 와 음성과학, 5(1), 39-46.

신가은, 하지완(2015). 말소리장애 아동의 조음복잡성에 따른 비유창성 및 조음오류 특성. 언어치료연구, 24(1), 91-102.
안미연(2018). 뇌성마비의 종류. 한국의료재단 공식블로그. https:// hworld.org/385.

양민교, 최예린, 김은연, \& 유현지. (2018). 기능적 조음음운장애 아동의 치조 마찰음 왜곡의 음향음성학적 특성. 말소리와 음 성과학, 10(4), 127-134.

유영신, 장승진, 백승재, 최예린(2010). 구개파열 아동과 정상 아 동의 마찰음과 파찰음의 음향음성학적 특성 비교. 한국콘텐 츠학회논문지, 10(5), 285-295.

이영미, 성지은, 심현섭(2013). 뇌성마비로 인한 마비말장애 성 인의 자음 오류 분석. 말소리와 음성과학, 5(1), 47-54.

이은주, 한진순, 심현섭(2004). 조음복잡성이 비유창성과 조음 오류에 미치는 영향. 언어청각장애연구, 9(3), 139-156.

이장신, 이지윤, 김선희 (2020). IOPI 를 활용한 조음기관 훈련 프 로그램이 경직형 마비말장애의 조음 능력에 미치는 영향. 재 활치료과학, 9(1), 91-99.

최영미. (2019). 러시아어 화자가 발음한 한국어 파찰음의 음향. 음성학적 특징. 한말연구, 51, 215-252.

\footnotetext{
* 본 연구는 문화체육관광부 및 한국콘텐츠진흥원의 연구개발지원사업으로 수행되었음(과제번호: R2019080018).
} 